\title{
A History of the Process of Capital Accumulation in Pittsburgh: A Marxist Interpretation-Part II
}

\author{
David Houston*
}

\section{MONOPOLY CAPITAL: ACCUMULATION WITHOUT DEVELOPMENT ABSOLUTE GROWTH AND RELATIVE DECLINE 1901-1950}

The period of monopoly capital is one of transition for the Pittsburgh region. It is interesting primarily for what preceded and followed it rather than for the developments within it. There were important changes in these 50 years, but they often reflected a response to forces outside Pittsburgh. In the last three decades of the 19th century the economy was dynamic and had a sense of internally caused expansion. Important innovations and inventions in steel processing, coke making, aluminum, carborundum, glass production, electricity and electrical machinery all reflected the competitive character of the accumulation process. The great fortunes (Carnegie, Frick, Phipps, Hillman, Mellon) were already made or the base was already established by 1900 . In terms of overall accumulation finance capital was central, and the great capitalists were great because they bought and sold enterprises rather than because they managed the production of a commodity. Labor too, by the beginning of the 20th century was highly developed as a force of production. There had been developed great unions and great strikes and struggles against capital. The working class existed and so did working class consciousness.

It is more difficult to generally characterize the next 50 years of Pittsburgh history because it is not so dramatic. The monopolization of capital continued and accumulation became more controlled. The structure of Pittsburgh's economy made it oversensitive to external events and it thrived during the two world wars and suffered severely during the depression. Andrew Mellon's decade in the 1920's as U.S. Treasurer was a local reflection of the increasing relations between monoply capital and the state. The working class was organized in this period but as much by capital and the New Deal as by itself.

\footnotetext{
†Editor's Note: Volume 9, No. 1 of this journal contained Part I of Professor Houston's paper tracing, from a Marxist perspective, the process of capital accumulation in Pittsburgh. Part I examined the period from 1800 to 1901. In Part II, Professor Houston continues his analysis, focusing on the years from 1901 to 1950, calling it a period of "Monopoly Capital: Accumulation without Development." Part III, the concluding portion of Professor Houston's paper will be published in Volume 10, No. 2.
}

* Professor of Economics, University of Pittsburgh. 
Unions became a socially accepted element in the accumulation process, but class consciousness was exorcised. Real wages in manufacturing in Pittsburgh rose at an average annual rate of $1.3 \%$, and the major wage gains from unionization would come in the period following.

At the end of World War II the United States was the strongest of the capitalist economies and was ready to assume the leadership of the international accumulation process. Capital in Pittsburgh too was shifting its focus from national to international accumulation. The shift from a regional to national to international orientation in the Pittsburgh economy is reflected in the changes from 1865 to 1950 . At the end of the Civil War Pittsburgh was still largely a regional economic center. Thirty-five years later, at the turn of the century, Pittsburgh was clearly oriented to national markets and economic events. By 1950 Pittsburgh capitalists were already grooming the city and region as a center in the international accumulation process. But before we examine this restructuring of the Pittsburgh economy we must study it's era of monopoly capitalism.

\section{Population and Labor Force}

Examining Table 8 we see that the regional population doubled from 1900 to 1950 while the City of Pittsburgh rose by only $40 \%$. Whereas the urban core contained $45 \%$ of the regional population at the turn of the century it accounted for only $31 \%$ by 1950 . In addition there was little growth in the city after 1920, and the population was essentially constant from 1930-50. Thus the trend of increasing regional concentration of population in the 19th century is reversed in the 20th century. Allegheny County outside the city and the peripheral counties show the most rapid population increases. The reasons for this dispersal have been well documented, but which are cause and which effect is not so clear. New modes of transportation especially the truck and car permitted cheaper and more ubiquitous transportation throughout the region. Energy distribution systems permitted freer location for production activities, and capital realized that the effect of workers living in a community adjacent to the factory was to heighten class consciousness and workplace-community solidarity. Consequently, dispersed working class residential developments were viewed favorably by both capital and labor if not for the same reasons. All of these elements, coupled with new assembly line techniques, required greater land areas only available in the periphery of the region. Of course, it is true that the regional steel industry was already a heavy land and water user and was well dispersed along the rivers. Comparatively speaking, the irregular topography of the Pittsburgh region probably dampened the spread effect to a degree.

The Pittsburgh metropolitan area population grew faster than the U.S. in the first decade of the period, then at an equal rate, and more slowly than the country as a whole for the last two decades, 1930-1950. Table 9 gives the proportion of the region to U.S. for a number of variables, and reflects the general 
TABLE 8

Absolute and Relative Growth in the Pittsburgh Standard Metropolitan Statistical Area and Its Components

1900-1950

\begin{tabular}{|c|c|c|c|c|c|c|}
\hline & $\begin{array}{l}\text { City } \\
\text { Pgh } \\
(000)\end{array}$ & $\begin{array}{l}\text { Rest of } \\
\text { Allegheny } \\
\text { County } \\
(000)\end{array}$ & $\begin{array}{l}\text { Allegheny } \\
\text { County } \\
(000)\end{array}$ & $\begin{array}{c}\text { Beaver } \\
\text { Wash } \\
\text { Westmore- } \\
\text { land } \\
(000)\end{array}$ & $\begin{array}{l}\text { SMSA } \\
(000)\end{array}$ & $\begin{array}{c}\text { U.S. } \\
(000,000)\end{array}$ \\
\hline 1900 & 483 & 292 & 775 & 309 & 1084 & 76 \\
\hline 1950 & 677 & 838 & 1515 & 698 & 2213 & 152 \\
\hline Change & 194 & 546 & 740 & 389 & 1129 & 76 \\
\hline$\%$ Change & 40 & 187 & 95 & 126 & 104 & 100 \\
\hline
\end{tabular}

Source: U.S. Census of Population

picture of Pittsburgh's development in the first half of the 20th century. Absolutely the region grows in population, jobs, and output, but after 1920 it fails to keep pace with the national economy. The regional commitment, developed in the prior period, to heavy manufacturing and especially steel is probably the single most important factor accounting for this pattern. A more detailed look at steel below will bear this out.

The composition of the Pittsburgh population altered significantly in this period as an examination of the number and distribution by origin of foreign born Pittsburghers shows in Table 10.

TABLE 9

The Pittsburgh Region as a Percent of the U.S. in Population, Employment and Production Workers 1870-1980

\begin{tabular}{ccccc}
\hline Year & Population & Employment & $\begin{array}{c}\text { Manufacturing } \\
\text { Year }\end{array}$ & $\begin{array}{c}\text { Production } \\
\text { Workers }\end{array}$ \\
\hline 1870 & 1.02 & & & 1.9 \\
1880 & 1.05 & & & 2.0 \\
1890 & 1.25 & & & 2.5 \\
1900 & 1.43 & & & 3.0 \\
1910 & 1.60 & & & 3.0 \\
1920 & 1.66 & & & 2.9 \\
1930 & 1.65 & 1.55 & 1939 & 2.6 \\
1940 & 1.58 & 1.39 & 1947 & 2.4 \\
1950 & 1.45 & 1.37 & 1958 & 2.4 \\
1960 & 1.33 & 1.26 & 1967 & 1.7 \\
1970 & 1.17 & 1.11 & 1977 & 1.1 \\
1980 & 1.01 & 1.01 & & \\
\hline
\end{tabular}


TABLE 10

Foreign Born People in the Pittsburgh Region

\begin{tabular}{|c|c|c|c|c|c|}
\hline \multicolumn{3}{|c|}{ No Foreion } & \multicolumn{3}{|c|}{$\%$ Dist. of Foreign Born } \\
\hline Years & $\begin{array}{l}\text { Born } \\
(000)\end{array}$ & $\begin{array}{l}\% \text { of } \\
\text { Pop }\end{array}$ & $\begin{array}{c}\text { Northern } \\
\text { Europe }\end{array}$ & $\begin{array}{l}\text { Eastern } \\
\text { Europe }\end{array}$ & $\begin{array}{c}\text { Southern } \\
\text { Europe }\end{array}$ \\
\hline 1870 & 94 & 19 & 98 & & \\
\hline 80 & 109 & 17 & 96 & & \\
\hline 90 & 190 & 21 & 86 & 10 & 3 \\
\hline 1900 & 247 & 21 & 64 & 27 & 7 \\
\hline 10 & 401 & 25 & 37 & 47 & 14 \\
\hline 20 & 388 & 20 & 28 & 47 & 22 \\
\hline 30 & 344 & 16 & 27 & 42 & 28 \\
\hline 40 & 275 & 12 & 24 & 45 & 29 \\
\hline 50 & 218 & 9 & 21 & 44 & 31 \\
\hline
\end{tabular}

Source: Lowry, p. 39.

The peak in both numbers and as a percentage of total population was reached in 1910, when the proportion of foreign born was one in four. The waves of immigration in time show the predominance of first northern Europeans, then central and eastern Europeans and finally southern Europeans. The pattern of foreign migration follows closely the economic pattern of growth, stability and decline. The restrictions in immigration in the 1920's probably had little effect on the reduced migratory flows to Pittsburgh. These flows reflected its constant, and then declining economic opportunities.

The foreign immigrants served the accumulation process well. Often, from rural decaying feudal relations they frequently accepted wages below the normal costs of reproduction of labor power. They swelled the reserve army of labor and thus depressed the general wage level. Culturally and geographically uprooted, unable to speak the language, they had little ability to organize in opposition to capital. Native workers were usually hostile and discriminating toward them, and hence the overall unity of the workers was weakened. Always in a minority they were forced to cluster in central city, mill town and mining town ghettos which may have made their numbers appear greater than if they had been dispersed. The discrimination and hostility manifest toward the foreign worker by the native Pittsburgher was most likely the result of their own insecure position in the accumulation process. The divisions which resulted within the working class were not really overcome until the 1930's with the victories of the union movement.

The growth of the black population, which was and is primarily located in the central city, parallels that of the foreign immigrants. In 1900 there were only 36,000 black people in Pittsburgh, $7 \%$ of the city and $3 \%$ of the regional population. By 1930 the black population reached 108,000, 16\% of the city and 5\% of the region. After 1920 there was no net immigration, and popula- 
TABLE 11

Industry Percentage Distribution of Workers

\begin{tabular}{lcccc}
\hline & $\begin{array}{c}\text { City of } \\
\text { Pittsburgh } \\
\text { Industry }\end{array}$ & $\begin{array}{c}\text { U.S. } \\
\text { Pgh }\end{array}$ & $\begin{array}{c}\text { SMSA } \\
1950\end{array}$ & $\begin{array}{c}\text { U.S. } \\
\text { Manufacturing }\end{array}$ \\
Trade & 45.1 & 43.3 & 46.3 & 38.0 \\
Transportation & 14.5 & 14.7 & 19.9 & 22.3 \\
Domestic \& Personal & 8.9 & 10.6 & 10.0 & 9.3 \\
$\quad$ Service & 14.3 & 15.5 & & \\
Professional & 4.9 & 6.9 & 5.0 & 7.4 \\
Clerical & 10.3 & 6.9 & 8.6 & 9.9 \\
Public Service & 2.0 & 2.0 & 3.7 & 8.1 \\
Total Number (000) & 231.8 & 24,500 & 757.8 & 47.6 \\
\hline
\end{tabular}

Source: Census of Population 1910, 1950.

Note: Agriculture and Mineral Extraction were removed from data before the percentage distribution was calculated. 1950 Data has been aggregated to correspond roughly to 1910 categories.

tion gains among blacks were due to natural increase. By 1950 there were 139,000 black people, $21 \%$ of the city population and $6 \%$ of the regional totals. Thus, Pittsburgh participated in the black migrations from South to North at the end of the 19th and beginning of the 20th century, but the later black migrations by-passed Pittsburgh with its declining economic opportunities. As a result the black population in Pittsburgh is older and more rooted in the community than in many other urban areas.

Total migration patterns in the Pittsburgh region reflect the same faltering accumulation process. Absolute growth in the population obscures the fact that more people have been leaving the region than coming to it since 1920 (Lowry, p. 42). Natural increase more than accounts for population growth, and so Pittsburgh has been "exporting" people for more than half a century. Here the connection between accumulation, labor markets and migration is a clear and stark reality.

How was this labor force distributed by economic activity in Pittsburgh? The specialization in heavy manufacturing, particularly steel, is well known. But looking at a more aggregate level in Table 11 we see that Pittsburgh in the beginning of the period was not so different from the U.S. as a whole as it was by 1950 . The data as will be seen are not strictly comparable, in that the data for 1910 are for the city of Pittsburgh while the 1950 data are for the SMSA, but probably reflect the aggregate categories fairly.

In 1910 the city of Pittsburgh was only slightly more specialized in manufacturing than the country as a whole. While it is true that many of the large steel works were outside the city proper, the proportion in manufacturing for the SMSA for which the data is not available in 1910, would probably not be very different. The largest variation in 1910 appears in the clerical occupa- 
tions since by this time Pittsburgh city had developed an extensive central business district (CBD) with corporation headquarters and the attendant managerial and clerical functions centered there.

Looking at the data 40 years later for the metropolitan area and the U.S. we see some of the anticipated shift from manufacturing to service activity. But Pittsburgh is lagging behind in this major structural development. Now overspecialized in manufacturing it has a shortage of trade, professional public administration workers all of which are related to the newly developing tertiary economy. The employment by occupation for 1950 data gives similar results. Pittsburgh compared to the U.S. has a surplus of craftsmen, operatives and laborers and a shortage of manager, professionals and service workers. The calculations from the Pittsburgh Regional Planning Association study (Region in Transition, p. 45) show a Pittsburgh deficit of $4.2 \%$ in white collar occupations and a surplus of $3.9 \%$ in blue collar occupations when compared to the U.S. This is attributed to industrial mix.

The development of Pittsburgh's labor force in the first half of the 20th century reflects the general pattern of accumulation: modest absolute growth, relative decline and continued specialization in an industrial structure that was becoming outdated.

\section{Manufacturing in Pittsburgh, 1900-1950}

By the turn of the century Pittsburgh was established as a manufacturing center par excellence. The next half century showed a continuation of this development with increased output, employment, and population. But lurking beneath the surface of these optimist statistics were indications of Pittsburgh's declining pre-eminance. Its growth both when compared to the previous era and to the U.S. as a whole showed a relative slipping. The decline began in this period, but it was not until after 1950 that it became precipitous.

Several factors account for Pittsburgh's economic development in this period. First, the area's initial advantage was substantial and could not be overcome quickly. Even though the market was shifting westward this was still a limited development which was interrupted after 1930 by both depression and war. Second, was the formation here of the greatest steel monopoly in the world. The Pittsburgh mills were the center of U.S. Steel's production, and this was bound to be a positive influence for the area in terms of innovation and levels of output. The technological lag which was later to overtake Pittsburgh and indeed much of the national steel industry was not a serious factor. Finally as the data show two world wars provided the greatest stimulus to the manufacturing based Pittsburgh economy. Table 12 contains data on manufacturing in the Pittsburgh SMSA for the period from 1899 to 1947.

A comparison of value added in manufacturing in Pittsburgh with the nation as a whole as shown in Table 13 is instructive.

In the last 20 years of the 19th century Pittsburgh's net output in manufacturing was growing almost half again as fast as the U.S. total $(7.5 \% / y r$. vs. $5.2 \% / \mathrm{yr}$.) whereas in the first half of the 20th century the region's net output is 
TABLE 12

Manufacturing in Pittsburgh SMSA 1899-1947

\begin{tabular}{lccccccc}
\hline Year & $\begin{array}{c}\text { Expenses } \\
(\$ 000,000)\end{array}$ & $\begin{array}{c}\text { Capital } \\
(\$ 000,000)\end{array}$ & $\begin{array}{c}\text { Prod. } \\
\text { Workers } \\
(000)\end{array}$ & $\begin{array}{c}\text { Wages } \\
(\$ 000,000)\end{array}$ & $\begin{array}{c}\text { Total Emp } \\
(000)\end{array}$ & $\begin{array}{c}\text { Wages \& Sal Value Added } \\
(\$ 000,000)\end{array}$ \\
\hline 1890,000$)$
\end{tabular}

Sources: U.S. Census of Manufacturers.

McLaughlin, Glen E., Growth of Manufacturing Areas, Pittsburgh 1938.

* 1909 Data is for a slightly smaller area than the SMSA.

$\mathrm{e}=$ Estimated

growing at a rate equal to only $70 \%$ of the nation. Similarly when we look at value added per production worker which is a rough measure of productivity we see that in the 1899-1947 period that Pittsburgh's growth in productivity is lagging behind the U.S. rate. Finally, if we look at the proportion of total U.S. production workers in Pittsburgh (Table 9) we see that this ratio reached a peak of $3 \%$ in 1899 , held at that level for 20 years and then fell to $2.4 \%$ by 1947.

Production workers are the core of manufacturing activity and represent the source of surplus value. As can be seen from Table 12 their number grew erratically in this period. The five decades show the first two with increases followed by two of decline and a final decade of increase. It is clear that it is war production which causes the Pittsburgh economy to boom, and the high levels of production associated with World War II mask the long term decline.

In addition to the dependence on a war economy, Pittsburgh was also subject to more cyclical fluctuations than most urban areas and the nation as a whole.

TABLE 13

Average Annual Growth Rates in Value Added

\begin{tabular}{|c|c|c|c|c|}
\hline \multirow[t]{2}{*}{ Years } & \multicolumn{2}{|c|}{$\begin{array}{l}\text { Value Added in } \\
\text { Constant } \$\end{array}$} & \multicolumn{2}{|c|}{$\frac{\text { Value Added in Constant } \$}{\text { Production Workers }}$} \\
\hline & Pgh & U.S. & Pgh & U.S. \\
\hline $1879-1899$ & $7.5 \%$ & $5.2 \%$ & $2.1 \%$ & $2.3 \%$ \\
\hline $1899-1947$ & $2.6 \%$ & $3.7 \%$ & $1.3 \%$ & $1.7 \%$ \\
\hline
\end{tabular}

Source: Calculated from Census of Manufactures 
TABLE 14

Average Annual Growth and Variation of Manufacturing Production Workers

\begin{tabular}{|c|c|c|c|c|}
\hline & \multicolumn{2}{|c|}{ PGH } & \multicolumn{2}{|c|}{ U.S. } \\
\hline & Ave.Ann.Gr. & $\begin{array}{l}\text { Variation } \\
\text { from Constant } \\
\text { Growth }\end{array}$ & Ave.Ann.Gr. & $\begin{array}{c}\text { Variation } \\
\text { from Constant } \\
\text { Growth }\end{array}$ \\
\hline $1899-1914$ & $2.8 \%$ & $3.6 \%$ & $2.8 \%$ & $2.4 \%$ \\
\hline $1921-1935$ & $-.63 \%$ & $15.2 \%$ & $-.41 \%$ & $10.6 \%$ \\
\hline
\end{tabular}

Source: McLaughlin, op cit, pp. 86, 93.

As Table 14 demonstrates while the region's growth in the first part of the 20 th century was equal to that of the nation the cyclical variation was roughly $50 \%$ greater. In the 1921-1934 period the area declined more precipitously and again experienced $1 \frac{1}{2}$ times as much cyclical variation as the U.S. Additional data show that after Detroit, which grew from 1921-35, Pittsburgh had the greatest variation from constant growth (cyclical fluctuation) of the 13 largest industrial areas.

To summarize then, manufacturing activity which was the economic base of the region showed absolute growth, relative declines, a dependence on war booms and high cyclical instability. Peak manufacturing production worker employment was reached in 1947, but it had been swelled by war expansion, and the weakness of the accumulation process which had been exposed between the wars was soon to be permanently revealed.

Steel

At the center of Pittsburgh manufacturing is steel and the other "metals" activities. The relative importance of these activities remained at between 70 and $75 \%$ of all manufacturing throughout this period whereas for the country as a whole the average concentration of the metals group was about half as much-35\% to 40\% (Region in Transition, p.142)* There was little adjustment in the economic structure which was cast in steel. The general picture of steel in Pittsburgh during this period can be summed up briefly: regional steel production was $30 \%$ of the nation's total in 1900, 22\% in 1930 and $20 \%$ by 1950 even though output was three times as large by the end of the period (Region in Transition, p.271).

Table 15 compares regional and national growth rates and also reveals the boost that war production provided to the steel industry both locally and nationally. Overall Pittsburgh output grew at about half the national rate. At least three factors can be cited as responsible for this slower growth. One of

*"Metals" include all metal production and fabrication, machinery, and transportation equipment. 
TABLE 15:

Annual Growth Rates of Steel Production 1901-1950

\begin{tabular}{llr}
\hline Year & U.S. & Pgh. \\
\hline $1901-20$ & $7.4 \%$ & $4.0 \%$ \\
$1920-40$ & 1.8 & .6 \\
$1940-50$ & 3.7 & 2.3 \\
\hline
\end{tabular}

Source: Calculated from data in Region in Transition, p.271.

the area's significant advantages, Connellsville coke was greatly reduced by the introduction of by-product coke process where coke is produced at the blast furnace. (What's bad for the region may not be bad for the region's capitalists. In 1915 Andrew Mellon bought the Koppers patents for the byproduct coke ovens and moved the firm's headquarters to Pittsburgh.) The substitution of open hearth for Bessemer steelmaking permitted the use of more scrap for pig iron and Pittsburgh was short on scrap and so had higher scrap iron prices. Finally the shift of population westward meant a shift in geographic demand which could only favor producers closer to the new markets (Region in Transition, pp. 273-278). Even though the region's output tripled most of this increase could be attributed to new technology and expansion of existing works rather than new construction. After 1901 four new integrated steelworks were constructed all outside Allegheny County: 1902 Monessen (U.S. Steel); 1904 Donora (U.S. Steel); 1909 Alliquippa (J\&L); and 1911 Midland (Crucible). However, in terms of increases in steel capacity between 1901 and 1916 these new plants accounted for little more than a third of the new regional capacity (Region in Transition, p. 271). The bulk of the new capacity was the result of modifying and expanding the older works.

The history of steelworkers in this period reflects a mixture of the movements of the accumulation process and varying levels of class struggle. As a generalization when the industry boomed the worker's position was strengthened and yet the worker's greatest victory came in the 30's, a decade of depression. After the defeat at Homestead the Amalgamated Association of Iron and Steel Workers, primarily a skilled worker's union, never regained their strength. After two unsuccessful strikes, one in 1901 and another in 1910, Amalgamated continued to exist as a workers organization, but was not effective in bargaining with steel companies (Hogan, pp. 443-444).

In the early part of the century wages for common unskilled labor rose while those of skilled labors (5\% of the work force) fell sharply. This was due to reorganization of work, in which the autonomy of the skilled worker who would himself employ helpers was eliminated, the defeat of the union, and the introduction of new technology. Average annual real wages of a steelworker in 1910 were $\$ 697$ (Hogan, p. 447), about $\$ 6600$ at today's prices. World War I increased demand, created a labor shortage and raised wages sharply for a few 
years. Then they leveled off during the 1920's. Real wages for common unskilled labor rose from 1900 to 1930 at an average annual rate of $1.2 \%$.

During World War I labor shortages in steel production were often met by encouraging migration of black workers from the South. By August 1917 there were 4000 black workers in the Carnegie plant in Pittsburgh and 1400 in J\&L and smaller groups elsewhere (Hogan, p. 256). But racism, housing problems, and lack of experience in steelmaking led to high turnover among black workers, and hence they never enabled capital to overcome the labor shortage during the war. Still by 1920 black workers accounted for $11 \%$ of the steelworkers in Pennsylvania and this proportion held in 1930 (Hogan, p. 861).

The wartime experience of labor shortages and rising wages encouraged the militancy of steelworkers especially the unskilled.* The Amalgamated tripled its membership to 19,000 between 1913 and 1917. But it was the industrywide National Committee for Organizing Iron and Steelworkers which was successful in organizing 100,000 steelworkers, about $20 \%$ of the total, by mid 1919. The rank and file confronted with layoffs voted overwhelmingly to strike. Judge Gary, head of U.S. Steel, refused to negotiate, and even though Gompers, the head of the A F of L, did not favor a strike, on September 21, 1919, 275,000 workers quit the mills and a month later 350,000 were out. Some steel producing districts were shut down completely, and in Pittsburgh $75 \%$ to $85 \%$ of the mills were affected. Still Gary refused to bargain. Public support was initially with the workers, but the companies successfully redbaited the union especially one of its leaders, William Z. Foster. The "red scare" caused the government which had been supportive to withdraw its support. A further problem was the weak organizational form of the National Committee which was simply a loose confederation of many unions. In fact, the Amalgamated ordered its members back in November. The strike lasted 110 days and its defeat laid to rest the unionization of steel for another decade and a half.

During the first three decades of the 20th century there was an evolution in capital-labor relations in steel. Various labor shortages had forced capital to grant a variety of concessions although usually under its control and within company organizations. After 1910 various safety rules and procedures were adopted which reduced accidents significantly. In 1923 the eight hour day was finally put into effect. Also during the 1920's and 30's, the companies developed Employee Representation Plans which permitted some negotiation between workers' representatives and management, and a grievance procedure.

The unionization of steelworkers in 1937 and steel capital's acceptance should be seen as a culmination of the history of capital-labor struggles and of the problems of accumulation in steel. On capital's side it was confronted with

\footnotetext{
*This account of the 1919 steel strike is taken from Hogan, pp. 456-459.
} 
a highly erratic demand with cyclical peak and troughs greater than average. Managing a labor supply under these demand conditions was difficult. After 1924 cheap foreign labor dried up because of the immigration quotas, and using minority (blacks and Mexicans), that is extra exploitable, labor was always difficult because of racism and cultural chauvinism. Establishing a union to regulate the supply of labor in these difficult demand conditions made a great deal of sense. In addition the New Deal was an important part of building and maintaining the Corporate Liberal State, a strategy favored by a significant part of the capitalist class. The New Deal encouraged unionism as a way of "managing" labor, and the laws, specifically the Wagner Act, recognized the right to organize.

From labor's perspective the steelworkers had always understood the need for a union as Homestead and the Strike of 1919 testify. The need to have an organization to protect them from the visisitudes of the accumulation process was obvious. In the 30's there were several factors favoring workers in the class struggle and steelworkers in particular. Worker's militancy was increased because of the Great Depression and the questions it raised concerning capitalism as a system and especially capitalists as a ruling class. Many successful union drives had already occurred. The state, at least at the federal level, was supportive. In the case of steel for the first time there was an effective nationwide Steel Workers Organizing Committee (SWOC), which was well financed and led by experienced organizers. Further, in 1937 the demand for steel was strong (20\% above 1929), and after the lean years of the early 30 's no firm wanted to be closed by a strike during a peak demand period (Hogan, pp.1173-1176).

Thus both short run and long run considerations converged to create the SWOC-U.S. Steel agreement of March 2, 1937 which recognized SWOC as the collective bargaining agent. Some of the smaller companies held out for a longer time, but with the right to collective bargaining supported by the government the unionization of all steelworkers was inevitable, and by 1942 , through elections, hearings, and negotiations, all the significant steel companies were organized. Pittsburgh's steelworkers after four decades and many struggles were once again unionized.

The Pittsburgh working class has historically been known for its militancy which has probably been due to the era of its growth and the conditions of exploitation more than anything else. From 1870 to 1910 capitalists in the U.S. had an essentially free hand in the exploitation of labor. The years 1910 to 1930 saw some modifications and constraints such as shorter hours, safer working conditions, which ameliorated the worst abuses of the accumulation process. In these conditions class antagonisms were obvious and inevitable. More concretely, erratic employment and wages, coupled with substandard living conditions (housing, sanitation, pollution) all conspired to make Pittsburgh working people more willing to strike and fight.

Examining one chronology of events there were 43 significant strikes in this period (Lorant, pp.472-495). Many of the strikes occurred in large industries 
TABLE 16

Values of Manufacturing in the Pittsburgh Region and the US 1899-1947 $(000,000)$

\begin{tabular}{|c|c|c|c|c|c|c|c|c|c|}
\hline Year & $\mathrm{c}_{\mathrm{tm}}$ & $\mathrm{c}_{\mathrm{d}}$ & $=$ & C & V & S & $\begin{array}{l}\text { Total } \\
\text { Value }\end{array}$ & $\mathrm{q}=\frac{\mathrm{C}+\mathrm{c}_{\mathrm{rm}}}{\mathrm{V}}$ & $\begin{aligned} P= & \frac{s}{C+V} \\
& +c_{r m}\end{aligned}$ \\
\hline \multicolumn{10}{|c|}{ United States } \\
\hline 1899 & 6,576 & 898 & 7,474 & 8,975 & 1,893 & 1,856 & 11,233 & 8.2 & .11 \\
\hline 1909 & 12,800 & 1,843 & 14,643 & 18,400 & 3,205 & 3,112 & 20,960 & 9.7 & .09 \\
\hline 1919 & 35,594 & 4,447 & 40,041 & 44,500 & 9,664 & 9,731 & 59,436 & 8.3 & .11 \\
\hline 1929 & 38,550 & 6,500 & 45,050 & 59,000 & 10,885 & 13,134 & 69,069 & 9.0 & .12 \\
\hline 1939 & 32,160 & 6,800 & 38,960 & 52,000 & 8,998 & 8,699 & 56,657 & 9.4 & .09 \\
\hline 1947 & 107,100 & 12,000 & 119,100 & 120,000 & 30,244 & 32,046 & 181,390 & 7.5 & .12 \\
\hline \multicolumn{10}{|c|}{ Pittsburgh } \\
\hline 1899 & 320 & 45.7 & 365.7 & 457 & 83.1 & 46.2 & 495.0 & 9.3 & .05 \\
\hline 1909 & 367.0 & 64.0 & 431.0 & 643 & 90.0 & 58.0 & 597 & 11.2 & .05 \\
\hline 1919 & 1129 & 107 & 1236 & 1074 & 366 & 269 & 1871 & 6.0 & .10 \\
\hline 1929 & 1159 & 130 & 1289 & 1296 & 388 & 388 & 2015 & 7.3 & .14 \\
\hline 1939 & 858 & 123 & 981 & 1230 & 270 & 250 & 1501 & 7.7 & .11 \\
\hline 1947 & $2768^{\mathrm{e}}$ & 186 & 2954 & 1857 & 807 & 711 & 4472 & 5.7 & .13 \\
\hline
\end{tabular}

Source: Census of Manufactures

$\mathrm{c}_{\mathrm{d}}$ (Depreciation) is estimated at $10 \%$ per year.

$\mathrm{e}=$ estimated

such as steel, glass, electrical machinery, and mining. Probably the organization and militancy of these workers carried over into other parts of the working class. The city transportation workers struck frequently, as did the taxi drivers. Hotel service workers, parking lot and garage attendants, firefighters, and public utility employees had strikes, and garbage collectors at one point had eight strikes in three years. Thus class struggle in its economic form has always been a very visible part of Pittsburgh's accumulation process. It is the vigor, the brutality and the large scale of that accumulation process which gives the struggle between the classes its particular character in this region.

\section{Analysis in Terms of Marxiam Value Categories}

A review of the data from the Census of Manufactures put in Marx's value categories as shown in Table 16 permits a further examination of Pittsburgh's economic development and a comparison with the U.S. All of the caveats made with respect to the similar analysis in Part I should be kept in mind in reading what follows. First we can see the not surprising fact that surplus value (S) increased continuously throughout the first half of the century with the exception of the depression year 1939. Since according to Marx the accumulation of surplus value is the raison d'etre of capitalism the increasing mass of $\mathrm{S}$ is what is expected. Additionally, we see that the two World Wars increased 
surplus value even more dramatically and in at least the second case rescued a stagnating accumulation process.

The organic composition of capital, the stock of constant capital divided by variable capital, shows no general increase in this period as it did in the earlier one. Either the cheapening of the means of production or the increasing education and training of the labor force or both could account for this. It is surprising that the organic composition of capital is larger in the U.S. than in the Pittsburgh region for most years, since Pittsburgh is a "heavy industry" town. The lower q's in the "war years," 1919 and 1947, probably result from the ability of capital to expand its variable capital more rapidly than constant capital, for example operating a plant at $100 \%$ plus capacity.

Apart from the first two data points where there may be measurement errors the profit rate in Pittsburgh compares favorably with the U.S. as a whole. Thus even though Pittsburgh began in this period to be a shrinking part of a growing pie, profitability in the basic accumulation process seemed to hold up. Also, there is no evidence at either level supporting the falling rate profit hypothesis. Any tendencies inherent in the accumulation process to cause the rate of profit fall in the long run must have been countered by other factors such as the monopolization and internationalization of Pittsburgh and U.S. capital. Additionally, the emergence of the modern capitalist state has affected the accumulation process in a variety of complex ways not encompassed in the simple falling rate of profit theory. On the whole, Marx's value analysis for this period while it does reveal the general character of the accumulation process does not fit any sharp theoretical formulations or hypotheses.

As in Part I we can again investigate an aspect of the quantitative economic class struggle or the division between labor and capital by looking at the workers' share of value. If wages are keeping pace with productivity the ratio of wages to value added will remain constant. As can be seen from Table 17 production workers share of value added remained fairly constant over the period and tended to be higher during the war periods. A high rate of economic activity as was produced during the two world wars favors labor in its attempts to increase its share. Pittsburgh production workers' shares were higher than the national average reflecting the relatively greater importance of direct production in the structure of the region's manufacturing. The rise in total wages to value added reflects the increasing importance of nonproduction workers (Marx's unproductive labor) in manufacturing. The relative balance of productive and nonproductive labor is shifting in favor of the latter though only moderately in this period. It is after World War II that a more rapid shift occurs.

\section{The Development of the Central Business District}

In this period Pittsburgh like most major U.S. cities developed a central business district (CBD). Today known as the "Golden Triangle," Pittsburgh's CBD is a compact 370 acres bound by rivers on two sides and sharply rising 
TABLE 17

Ratio of Production Workers Wages and Total Employees Wages to Value Added for the US and Pittsburgh 1899-1947

\begin{tabular}{ccccc}
\hline & \multicolumn{2}{c}{ U.S. } & \multicolumn{2}{c}{ Pittsburgh } \\
Year & $\begin{array}{c}\text { Prod. Wage } \\
\text { Value Add }\end{array}$ & $\begin{array}{c}\text { Tot. Wage } \\
\text { Value Add }\end{array}$ & $\begin{array}{c}\text { Prod. Wage } \\
\text { Value Add }\end{array}$ & $\begin{array}{c}\text { Tot. Wage } \\
\text { Value Add }\end{array}$ \\
\hline 1899 & .41 & .49 & .46 & NA \\
1909 & .39 & .50 & .42 & NA \\
1919 & .41 & .52 & .46 & NA \\
1929 & .36 & .47 & .40 & .51 \\
1939 & .37 & .52 & .42 & .56 \\
1947 & .41 & .53 & .47 & .60 \\
\hline
\end{tabular}

Source: Calculated from the U.S. Census of Manufactures.

hills on the third. It was the place of original settlement, but by 1900 with a population of nearly half a million the city had spread well beyond this limited area. After a century of chaotic land use development, Pittsburgh's downtown was a hodgepodge of uses which in many cases were not in tune with a rising center of capital accumulation.

The creation of the CBD can be viewed as both an economic process that is a result of the changing process of accumulation and a physical or architectural development. The opening of the 20th century saw the beginning of the era of monopoly capitalism, bringing with it various specializations, new emphasis in accumulation. First, we see a separation of the production and management functions within corporate capital. The exploitation of the productive labor became increasingly rationalized and carried out at arms length through Taylorism, personnel management, research and development. The various nonproductive functions were moved from the plant to a more pleasant environment where they could be in close contact with similar activities of other corporations. The idea of a corporate headquarters separate from the means of production and labor power was born. Additionally, it is seen as only fitting that these great vehicles for the accumulation of surplus value should be housed in quarters reflecting their wealth and power. Indeed as the gothic cathedrals before them they embody the great architecture of their time. Finally with the increasing scale of commodity production it became necessary to concentrate certain consumption goods so as to provide efficient markets, thus reducing the time capital spent in commodity form. So another important function of the CBD became retailing through great "department" stores.

The mechanism for achieving the transformation in land use was the full development of land rent. Each capital bid and the highest bid got the land. This form of treating land as a commodity though not new reached its highest development in the CBD's where a foot of street frontage sold for untold 
values. The result of course correlated with an increasing number of floors per building.

The physical transformation of Pittsburgh's CBD can be summarized as follows: (Lorant, pp. 471-484). Before 1900 there were two 15 story structures which constituted the "skyscrapers." Between 1900 and World War I twenty-two large structures ranging from 12 to 26 floors were built. They housed corporate headquarters, banks, hotels, city and county government and a variety of business, financial and retail services. Between 1923 and 1934 an additional 14 large buildings were constructed, some with over 30 stories. The depression and World War II temporarily halted the development of the CBD. It remained in limbo awaiting the power and money of Richard King Mellon and other Pittsburgh capitalists to give it a "Renaissance."

It is interesting in understanding Pittsburgh's development to compare this massive development of office and banking buildings in the first half of the century to the very limited building of new steel producing facilities. It reveals the relative emphasis on the circulation rather than the production of capital. True, Pittsburgh in this period is still a producing center of surplus value, but the shift away from production and the increasing attention to the circulation of surplus value is already evident.

\section{Political Structure and Urban Form}

Because Pittsburgh's development was so completely determined by individual private industrial capital accumulation its political structure was correspondingly weak and dependent. Local governments had only residial power and saw their role, then as now, primarily in fostering private accumulation. If anyone was going to regulate capital it would be capital itself, not city or county governments. This laissez faire attitude coupled with the terrain of Pittsburgh led to the formation of a variety of cities, towns, townships, boroughs and unincorporated places. By 1925 Allegheny County had about 125 different civil divisions with varying levels of provision or nonprovision of public services. The city of Pittsburgh was eager to recapture its "suburbanites," and consequently maintained continuous pressure through 1930 for annexation of adjacent smaller jurisdictions. In 1907, Pittsburgh annexed Allegheny City and increased its population by $40 \%$. Between 1908 and 1928 Pittsburgh annexed 28 more boroughs and townships. The struggle between the central city and the multitude of suburban communities over annexation and the creation of a metropolitan government came to a head in 1929 with the proposal of a federated consolidation of the city and Allegheny County. However, the voting requirements for passage were so strict that it was defeated and with it any serious hope for a politically coordinated treatment of the region's public problems and services (Lubove, pp. 97-100).

Most of the region's urban form was developed in this period. The natural elements, rivers, steep hills and limited level land, imposed the first and basic constraint. Heavy industry especially steel which was the core of the Pitts- 
burgh economy was the second locational force. The mills needed water, level land and access to the limited river shores provided it. Finally, the business activity created an agglomeration at the intersection of the rivers composed of the central business district, wholesaling, and a major transshipment point. The last major ingredient, housing, was left to forage for itself.

Both the terrain and the environment posed serious transportation and sanitation problems for residents, and the problem of adequate housing for the mass of the working class and poor was never really solved (Lubove, Chap. 4). If decent housing for the mass of workers could not be produced during an era of growth, it was unlikely to be realized in a period of relative decline. The poor housing conditions in the city at the beginning of the century coupled with two world wars and the Great Depression all conspired to produce little significant improvement in the overall housing stock. Of course, the bourgeoise and middle class created elegant and pleasant housing districts in the city and suburbs. But by the end of WWII probably close to $30 \%$ of the housing in Allegheny County was substandard.

Because of the terrain intra-urban transportation was both crucial and difficult and most of the system was developed in this period (Lorant, pp.470-495). Pittsburgh in 1900 had a variety of means of transportation: horse and buggy, cable cars, inclines, horse drawn rail cars, railroads, electric trolley cars, automobiles. A major "rapid transit" road had been constructed. In 1902, the merger of several companies created the Pittsburgh Traction Company, with 400 miles of track. An elevated railroad was opened in 1906. In 1907 there was first proposed a subway running from downtown to the East End. No subway has ever been built but the most recent proposals for this same route were made in 1978. Taxicab service began in 1909. In 1911 tolls were removed from five city bridges. Trolley and elevated services were expanding and new bridges were being constructed. In 1921 the first automobile parking regulations were passed but they were not seriously enforced until 1947. In 1922 the first of many Pittsburgh tunnels was opened. The following year a second major "boulevard" was opened, the first traffic signal system was installed, and the last horse car was removed. As early as 1921 traffic congestion was serious in the CBD, but it was not until 1939 that a comprehensive highway plan was developed, and this was not significantly implemented until after World War II. By the end of the period transportation in Pittsburgh was in serious need of revamping. The extensive trolley system was the main public transit, and the private automobile without adequate arterial roads was congesting the business center of the region. Improving the region's transportation system was to be a major component of the Pittsburgh Renaissance after World War II.

Drinking water was a serious health problem at the beginning of the century. Rivers served in many cases as both the source of drinking water and the depository of industrial and domestic sewage. Pittsburgh and Allegheny County had the highest typhoid fever death rates in the country with over 5000 cases per year (Lorant, pp.472-475, Lubove, p.13). As early as 1899 Pitts- 
burgh city council authorized a purifying system for the city water supply but it was not until 1908 that a filtration system was in operation. Sewage disposal was unsanitary and the streams and rivers of Allegheny County were all polluted. In 1938 the government estimated that it would take $\$ 25$ million to end stream pollution in the county. Again even a partial solution to this problem awaited the Renaissance.

The rivers which were an important element in making Pittsburgh a great industrial center were also the creators of periodic catastrophy. Floods had always plagued the Pittsburgh region. There were twelve major floods between 1900 and 1950. The first Flood Commission was appointed in 1908 and the solution to the problem of flooding was clear enough. It required a series of dams and reservoirs in the upper Ohio valley to control and regulate the flows during the Spring runoff of the melting snow. However, like most public projects this received more verbal than material support, and it took the great flood of 1936 to force a plan of action. The flood covered most of the downtown, some streets to a depth of 20 feet, took 74 lives, left 135,000 temporarily homeless and cost the region $\$ 150$ to $\$ 200$ million. The next year the ground was broken on the first of a series of 10 dams and flood control reservoirs.

Smoke and Pittsburgh have been synonomous for two centuries. The development of the steel industry and the rest of the industrial agglomeration by private capital with essentially no public regulation created an air pollution problem which was among the worst in the world. The problem was well recognized at the turn of the century, but since the costs of pollution are collective while the benefits accrue to individual capitalists no real support for the enforcement of the early local statutes $(1906,1914)$ could be found. Until capital was convinced that the costs of air pollution (e.g., cleaning bills, health costs, loss of executive and other skilled and professional labor) exceeded the benefits little was done. In 1941 a new city smoke control ordinance was passed but its enforcement was postponed until after the war. Again it was the forces of the Pittsburgh Renaissance, capital itself, which finally dealt with the air pollution problem on a limited level.

\section{REFERENCES}

Hogan, William T., Economic History of Iron and Steel Industry in the United States, Vols. 1-5, Lexington Books, 1971.

Lorant, Stefan, Pittshurgh, Doubleday, 1964.

Lowry, Ira S., Portrait of a Region. University of Pittsburgh Press, 1963.

Lubove, Roy, Twentieth Century Pittsburgh. John Wiley, 1969.

McLaughlin, Glenn E., Growth of American Manufacturing Areas, Pittsburgh 1938.

Pittsburgh Regional Planning Association, Region in Transition. University of Pittsburgh Press, 1963.

U.S. Bureau of the Census, United States Census of Manufactures, 1849-1977.

U.S. Bureau of the Census, United States Census of Population, 1800-1970. 